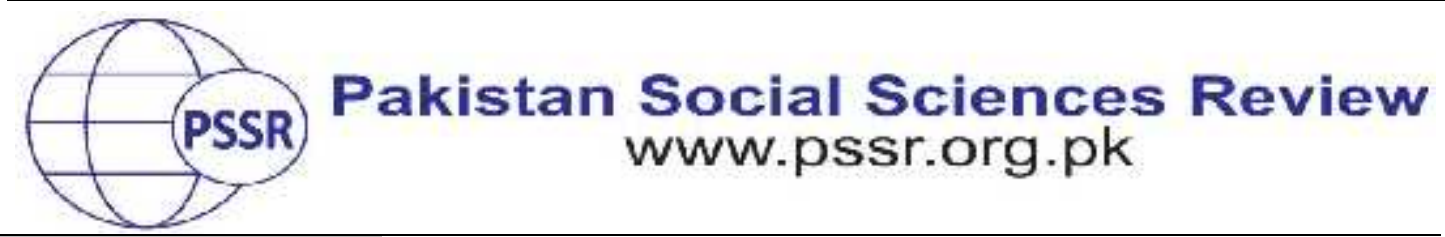

RESEARCH PAPER

\title{
Admiralty Jurisdiction of High Courts Ordinance 1980: A Critical Review
}

\author{
Dr. QamarAbad ${ }^{1}$ Dr. Ghulam Murtiza ${ }^{2}$
}

1. Head KPT Chair, Bahria University, Karachi Campus, Sindh, Pakistan

2. Assistant Professor, College of Law, Government College University, Faisalabad, Punjab, Pakistan

\begin{tabular}{|c|c|}
\hline PAPER INFO & כלק \\
\hline $\begin{array}{l}\text { February 11, } 2020 \\
\text { Accepted: } \\
\text { March 15, } 2020 \\
\text { Online: } \\
\text { March 30, } 2020\end{array}$ & $\begin{array}{l}\text { and applications } \\
\text { require to be } \\
\text { Admiralty law }\end{array}$ \\
\hline $\begin{array}{l}\text { ls: } \\
\text { Rem, } \\
\text { Courts, } \\
\text { nal } \\
\text { e, } \\
\text { and } \\
\text { ' } \\
\text { Lien. } \\
\text { est }\end{array}$ & $\begin{array}{l}\text { admiralty laws in Pakistan have been de } \\
\text { concisely adopted from the United K } \\
\text { Relevant laws in the United Kingdom ha } \\
\text { cater the contemporary needs of the } \\
\text { Notwithstanding the need to amend the } \\
\text { this article endeavor to highlight a slip in } \\
\text { the '1980 Ordinance'. Pakistani courts, in a }\end{array}$ \\
\hline $\begin{array}{l}\text { ponding } \\
\text { nurtiza }\end{array}$ & $\begin{array}{l}\text { rue } \\
\text { ogy } \\
\text { om } \\
\text { the }\end{array}$ \\
\hline
\end{tabular}

\section{Introduction}

The Admiralty Jurisdiction of the High Courts' Ordinance, 1980, is a major enactment of Admiralty laws in Pakistan.The AdmiraltyJurisdiction upon the High Courts in Pakistan had been conferred under the Colonial Courts of Admiralty Act 1890 U.K. The Act empoweredthe same jurisdiction upon the Colonial Courts as the Admiralty Courts in England.The Courts of Admiralty Act 1891 (Act XVI of 1891), Pakistan designatedthe Admiralty jurisdiction to the High Court of West Pakistan functioning as Admiralty Court. By virtue of succession the respective Admiralty jurisdictions have been delegated toHigh Courts in Pakistan. The powers of High Courts exercising Admiralty jurisdictions have been derived from the Admiralty Court Act 1861 U.K.(Hayat Shipping Agencies Ltd. v. Delta Pioneer, 1972).The 
amendments made in Admiralty laws under the Supreme Court of Judicature (Consolidation) Act 1925 as held in The Yuri Maru v. The Crownby the Privy Council does not apply or enhance the jurisdictions of Colonial Courts as it applies to the United Kingdom courts. The Courtsin Pakistan honor and bind them to the decisions of the Privy Council unless the Supreme Court of Pakistan held otherwise (Hayat Shipping Agencies Ltd. v. Delta Pioneer, 1972).The Admiralty laws in the United Kingdom were further amended by the Administration of Justice Act 1956 (U.K.). Henceforth, the Admiralty laws in Pakistan were also amended to give effect to the British statute by the enactment called 'Admiralty Jurisdiction of High Courts Ordinance 1980'. The 'Ordinance of 1980' has been derived from the above mentioned Act of 1956 (U.K.). The said act however, for unknown reasons, varies from its source in some respects. These said variations appear to the authors unwarranted and tainting the law with errors. One of these points will be discussed in the later part of this article while suggesting the correction(s) and amendment(s) in the statute.

Lately, in the United Kingdom, Admiralty laws have been amended under the'Senior Courts Act 1981 (U.K.)' to meet the contemporary needs and provisions of the international conventions. However, in Pakistan, no attempt as yet been made or even the need to do so has been realized. Maritime and Admiralty laws having international characternecessarily require conformity with international laws and standards (McNair, 1956).

July 2003, in Tasman Spirit incident, it was strongly felt that Pakistan lacks in legal framework and necessary updating and amendments in the relevant (Maritime and Admiralty) laws to respond such incidents involving international actors and interests. Disappointingly, Pakistan being non-signatory to the 1992 Civil Liability Convention (CLC) failed to effectuate compensation mechanism for recovering the costs of clean-up of spilled oils (amounting to 1.6 billion U.S. Dollars). A number of other incidents in Pakistani waters occurred where authorities and government functionaries failed to respond effectively in national interest. Such confusion continues till the case is finally closed without any conclusion. Similar state of confusion existedduring occurrence of every incident/accident of maritime natureincluding accidental beaching, intentional beaching of a ship for breaking with noxious and dangerous substances or residues harmful to humans and environments, discharging prohibited cargo residues and wastes etc. Lack of necessary legal framework and exercise of the rules and laws available, great difficulties are faced and the concerned departments left with bullying their responsibilities towards others and finally, no option but to close the case without a conclusion.

\section{Literature Review}

Maritime and Admiralty laws having international character necessarily require conformity with international laws and standards. The significance of updated Maritime and Admiralty laws in Pakistan has been felt constantly and 
various attempts have been made in this regard to make necessary modifications in the relevant laws and policies thereof. The said efforts though could not bring any significant change but successfully shed light on the issues. However, despite having some lacuna and areas needing special attention to legislate and amend the existing Admiralty laws in conformity with international conventions ratified by Pakistan is being highlighted in this article.

Pakistan Ship's Agent's Association (PSAA) and other organizations in the Maritime sector of Pakistan constantly and from time to time keep advising the government in respect of various amendments which are indispensable for their business in Pakistan.

With an aim to attract private sector to participate in maritime commerce and business, the government of Pakistan devised its Shipping Policy 2019 with incentives for private investors. These incentives include exemption from income and sales tax till 2030 as well as exemption from customs duties on ships purchased and brought from outside into Pakistan till 2030. In views of some shipping experts, it was a barrier to investors in the past to pay enormous amount of customs duties on ships purchased from outside Pakistan despite the fact that ships visit and leave the country. In authors' view, the attempt is without a potential to attract investments from private sector due to a number of other reasons. However, it endorses the fact that Maritime policies and laws need necessary amendments to meet the requirements of regional market.

The concerned ministries, the ministry of maritime affair and the ministry of commerce may expect in addition to introduction of new ships registration in Pakistan, considerable up gradation of fishing operations especially in the deep seas enabling enhancement of sea food export to a higher level. Consequently State Bank of Pakistan extended long term facility for merchant ships, fishing vessels and auxiliary crafts (tug boats, dredgers etc.). The importance of private investment in maritime sector was fully emphasized (Ministry of Maritime Affairs, 2019).

Notwithstanding the steps taken for improvement of maritime sector bringing desired results which remain beyond the reach in Pakistan, it is well clear that decline and inaction of maritime sector is mainly contributed to the lack of legal framework and policies supporting the said business.

In order to make headway to new legislative regime and amendments in Maritime laws in Pakistan, an attempt was made in 2005 by drafting proposed law/amendments in the statutory laws embodied in the Carriage of Goods by Sea Act 1925. Unfortunately, it could only attain the status of a bill in the Standing Committee though it was expected to become a statute called "The Carriage of Goods by Sea Act, 2011. The said bill failed to proceed further to legislative process due to various reasons, which will be discussed latter. It was plagued with disputes from parties with contrasting interests. Some traders and maritime personals called it completely in favor of shipping agents and freight forwarders without offering any protection to trade. They demanded a regulatory authority as guarding against fraud 
in Bills of lading and attempting conversion of goods. They demanded regulating sea freights as well. The proposed new law was drafted by the then Director General Ports \& Shipping and said to be with consent of stakeholders. The bill is alleged to be tampered to become against stakeholders. In an attempt to follow the English statutes, a second bill to enact 'Sea Carriage Shipping Documents Act, 2011' also prepared collaterally. Both bills were last sighted by the respective standing committee of the National Assembly on ports and shipping on September 26, 2011. The process under influence of business circles was proposed numerous amendments. Under the doldrums, the standing committee opted as usual in Pakistan to invite comments from the Ministry of Commerce (MOC), State Bank of Pakistan (SBP), and Federal Board of Revenue (FBR). The Committee while inviting various concerned circles for comments stated that it was an attempt to modernize old laws of the Carriage of Goods by Sea Act 1925 incorporating the provisions of international conventions relating to bills of lading subject to necessary amendments with a list of legal documents concerning the carriage of goods by sea. The Committee sought advice that why the two laws i.e. the Carriage of Goods by Sea Act 2011 and the Sea Carriage Shipping Documents Act 2011 should not be consolidated into one law.

The concerned departments responded interestingly leading to no solutions. The Ministry of Commerce (MOC)'s main concerns were 'the Sea Carriage Shipping Documents Bill 2011 and some definitions thereof. The said ministry made reference to the Carriage of Goods by Sea Act 1992 U.K.

The State Bank of Pakistan relied on the Logistic Service Providers Regulatory Authority Bill 2011 to safeguarding against allied risks.

The Pakistan Apparel Forum on one hand made reference to the international trade rules and practices and on the other hand advised deliberations with shipping lines and freight forwarders for finalizing amendments in the bill.

The stakeholders advised several amendments in the bill. These amendments mainly concern issuing of a bill of lading by the carrier; term 'consignee' to replace with 'cargo owner of the goods; deleting and replacing 'seaway bill' with 'carrier's bill of lading' etc. An apprehension of opening doors of malpractice by freight forwarders in connivance with shipping agents was expressed (Hamza, 2011).

\section{The Admiralty Jurisdiction of High Courts Ordinance 1980}

As mentioned earlier, the Act despite its derivation from the United Kingdom laws forming part of the Administration of Justice Act 1956 (UK) varied from its source in some respects for unknown reasons and one out of them is under discussion below.

\section{Beneficial Owner and Number of Shares}


Article 4 (4) of the 'Admiralty Jurisdiction of High Courts Ordinance1980', Mode of exercise of Admiralty jurisdiction provides powers under Admiralty jurisdiction to take action against a ship irrespective of an action against its owner.The article deals with conditions (one or more) necessary to meet for invoking an action in remto arrest a ship under Admiralty jurisdiction for satisfaction of a maritime claim. In brief, a maritime claim falling under Article 3 (2) of the Ordinance 1980 and fulfilling one or more conditions of sub-clauses mentioned hereinabove i.e.:

a. the maritime claim is in connection with a ship (not necessary the same ship);

b. where the "relevant person" (who would be liable on the claim in an action in personam) was at the time when cause of action accrued (first stage of action):

i. the ownerof the ship or;

ii. the charterer (any type) of the ship or;

iii. in possessionof the ship or;

iv. in control of the ship

In all the four cases mentioned hereinabove it is not necessary that the ship should be the same i.e. the offending ship. It may be a different ship than the offending ship meeting the conditions.

If any (or more) of the above conditions meet, an action in remmay be invoked against and the ship arrested irrespective of existence of a maritime lien on the ship(second stage):

a. the same ship if it is still, when the writ is issued is beneficially owned as respect majority shares by the relevant person or;

b. anyother ship(popularly termed sister-ship) which is beneficially owned as respect majority shares by the relevant person.

The content of Article 4 (4) of the Ordinance 1980 are similar to the content of Section 3 (4) of the Administration of Justice Act 1956 except that it reads 'all shares' unlike 'majority shares' in the Ordinance 1980. This contrast needs attention by the legal experts. In our opinion it is a result of lack in deliberations at the time of legislation or due to the concept of a ship being divided into 64 shares. There appears to be no logic to continue but to make corrections after due deliberations. Reference is made to the following grounds both internally as well as externally.

\section{Owner and Beneficial Owner}

The terms'beneficial owner' and 'beneficially owned' have not been defined in the statutes and left for the courts to construe from case to case basis. Generally they make reference to equitable rights in a property titled to a different person 
(Garner, 2001).It is worth noting that the terms 'owner' at the first stage when cause of action arose and 'beneficial owner' at the second stage when a writ is issued have been used with specific intent to distinguish between their nature and characters. In The I Congresso del Partido,Robert Goffconstrued the word 'beneficially' followed by the word'owned' in section 3(4) of the Administration of Justice Act 1956 (UK) (analogous to Article 4(4) of the Ordinance 1980), simply as a case in trusts to bind those interested in the ship operating under the cover of a trust from escaping liabilities and arrest of their ship. He expressly decided against 'The Andrea Ursula'.

\section{Appointment of Managing Owner}

Notwithstanding the number of owners (more than one) a ship may have or whose shares are owned by more than one owner, it is required to have one of those owners to have a status as owner or a person different from owners must be appointed as 'Managing Owner' and marked in the ships' Register. All correspondence shall be made in the name of 'Managing Owner' not 'owners of the ship or share- holders. It is worth noting that a ship having more than one owner or shares in a ship owned by more than one owner have though been mentioned distinctly but dealt with similarly in respect of the legal requirement to necessarily have a managing owner as mentioned above (Merchant Shipping (Registration, etc) Act, 1993, Section 23,Merchant Shipping Ordinance, 2001, Article 58). Article 57 of Merchant Shipping Ordinance 2001 (Pakistan) also refers to and binds the persons beneficially owning or interested in a ship other than its legal owner as well as its managing or entrusted owner against pecuniary liabilities. For example; aperson or persons beneficially interested in a ship other than a mortgagee of a ship or share(s) registered in some other person's name as (legal) owner shall be jointly and severally subjected to all pecuniary penalties imposed under law on the ship or share. As per Article 58 (1\&2) Ship's managing owner or a person entrusted by and designated by the managing owner to act in his capacity shall be registered in the customs house and subjected to the liabilities of the owner.

Thus a concept of single owner in all legal matters exists who for all legal purposes owns the ship and is responsible in the capacity of owner for all acts done by himself, his agents and servants (including master of the ship). It is to remember that while dealing with an action in rem against a ship, the ship itself is exposed to claims and liabilities arising thereof in case of its owner failing to respond as happens mainly under heavy maritime claims. This status of owner suitably fits the first stage of in remaction against a ship i.e. the relevant person who would be liable in an action in personam when cause of action accrued.The term 'beneficial owner' at the second stage of in remaction against a ship when it commences or when a writ is issued against the ship includes the 'owner' described hereinabove together with any or all who may not be legal owners but beneficiaries under trust or equitable owner(s) or others having shares in the ship or owning its shares in any numbers. The purpose to use the term beneficial owner or beneficially owned in respects all shares is to bind all against creating any hindrance in an action in rem toarrest a 
ship. This interpretation is based on Robert Goff observations in The I Congresso del Partido, supra.

Admiralty courts in Pakistan regard the words 'majority shares' attributed to the owner (not owners) (V.N. Lakhani and Company v. M.V. Lakatoi Express, 1994).The Court in Pakistan(Messrs Khadija Edible Oil Refinery (Pvt.) Ltd. v. M.T. Galaxy and 4 others, 2011) made reference to the EvpoAgnicand noted the material similarity between Section 21 (1) to (4) of the Senior Courts Act 1981 (UK) and Article 4 (4) of the Ordinance 1980 (Pakistan) (with distinction of all and majority shares therein respectively).The Court concluded on the basis of EvpoAgnic supra that: the idea of 'registered owner as nominal owner is expelled; ownership and registered ownership for the purpose of an action in rem against a ship are the same; on the notion of trust, resulting from a 'beneficial ownership' involves contrast between equitable and legal ownership which contradicts to the observationmade in $I$ Congresso del Partidoby Robert Goff J. supra beingnot known to many jurisdictions.

For further clarity reference may be made to international convention to resolve ambiguities or obscurities of language while interpreting the law (Salomon v. Commissioners of Customs and Excise, 1967). A reference to Ship Arrest Convention (International Convention Relating to the Arrest of Sea-Going Ships, 1952) may be beneficial in construing the provisions of law under discussion. According to the said convention:

A maritime claimant may arrest either an offending ship or any other ship (subject to limitations enumerated in Article 1 of the convention) owned by the person who was the owner of the offending ship when maritime claim arose (International Convention Relating to the Arrest of Sea-Going Ships, 1952, Article 3(1). Ships are deemed to be in the same ownership when all shares therein belong to the same person or persons (International Convention Relating to the Arrest of SeaGoing Ships 1952, Article 3(2).The convention makes no distinction between 'owner' or 'ownership' and 'beneficial owner' or 'beneficially owned'. The International Convention on Arrest of Ships, 1999 contains similar provisions under Article 3 except that it elaborates its provisions with more claritybutis silent on defining 'when ships may be deemed to be in the same ownership' as had been done in the convention of 1952. Reference to owner including beneficial owner is thus made in respect of all shares therein but not the majority shares.

Contrarily, if provisions of Ordinance 1980 were applied in respect to the majority shares in place of total shares, it would make the law redundant and meaningless. Those with minority shares may exercise their rights to avoid arrest of the ship due to a ship cannot be divided and partly arrested.

\section{Conclusions and Recommendations}

One of the errors/slips in the statute named 'The Admiralty Jurisdiction of High Courts Ordinance 1980 has been identified. In authors' opinions, there exist few more discrepancies and errors which necessarily require to be dealt with by 
experts in the maritime legislations. More areas, it is expected to be identified in the forthcoming research which requires attention and corrections. However, a dire need exists to modify and amend the Maritime and Admiralty laws to meet the contemporary environments and compliance with provisions of international conventions. It is therefore, recommended that relevant ministries should endeavor to carryout research in the Maritime and Admiralty legislationsto bring it in par with international laws. The universities imparting legal education should make necessary provisions to include Maritime and Admiralty laws in their curriculums. Higher Education Commission (HEC) should include development of professional legal education and research on priority basis in Maritime and admiralty laws and International Law of the Sea. 


\section{References}

Administration of Justice 1956 https://www.legislation.gov.uk/ukpga/1956/46/pdfs/ukpga_19560046_en.pdf

Garner, B. A. (2001). Black's Law Dictionary, Second Pocket Edition. St. Paul: West Group.

Hayat Shipping Agencies Ltd. v. Delta Pioneer (1972)PLD 1972 Karachi 442

Hamza, W. (2011, December 27), 'Carriage of Goods by Sea' bill approved Pakistan Todayhttps://archive.pakistantoday.com.pk/2011/12/27/\%E2\%80\%98carriageof-goods-by-sea $\%$ E2\% $80 \% 99$-bill-approved/.

International Convention Relating to the Arrest of Sea-Going Ships 1952 Retrieved from http://www.admiraltylawguide.com/conven/arrest1952.html.

McNair, L. (1956). International Law Opinions. Cup Archive

Merchant Shipping (Registration, etc) Act 1993 https://www.legislation.gov.uk/ukpga/1993/22/contents/enacted.

Merchant Shipping Ordinance 2001 http://www.ahmedandqazi.com/actsandregulations/shippingLaws/merchantS hippingOrdinance2001.pdf.

Messrs Khadija Edible Oil Refinery (Pvt.) Ltd. v. M.T. Galaxy and 4 others(2011) 2001 CLD 1329 Karachi

Ministry of Maritime Affairs, Government of Pakistan (2019). https://moma.gov.pk

Salomon v. Commissioners of Customs and Excise (1967) 2 Q.B. 116

The Andrea Ursula (1973) Q.B 265

The Evpo Agnic(1988) 2 Lloyd's Rep. 411

The 'I Congresso del Partido'(1977) I Lloyd's Rep. 536

The Yuri Maru v. The Crown (1927) A.C. 906

V.N. Lakhani and Company v. M.V. Lakatoi Express(1994)PLD 1994 SC 894 